\title{
Amulets used in Lincolnshire
}

\section{Mabel Peacock}

To cite this article: Mabel Peacock (1908) Amulets used in Lincolnshire, Folklore, 19:1, 87-88, DOI: $10.1080 / 0015587 X .1908 .9719812$

To link to this article: http://dx.doi.org/10.1080/0015587X.1908.9719812

$$
\text { 曲 Published online: } 14 \text { Feb } 2012 .
$$

$\sqrt{6}$ Submit your article to this journal $₫$

Џll Article views: 2

Q View related articles ¿ 
certain old Roman coins were long believed to be a sure protection against witchcraft, for children especially, and that to combat this profane idea the priests had these medals of the Three Kings made, which became known, like the ancient coins, as "witch medals" (medaglie delle streghe). They were worn by grown persons as well as by children, but more frequently by the latter. It has been reported that, within the past few years, the issue of the "witch medals" has been prohibited by the Church authorities, and that they are no longer distributed.

W. L. Hildburgh.

\section{AMULETS USED IN LiNCOLNSHIRE.}

A. R. TELIS me that charms made of bog-oak, locally called "car oak," are considered lucky. One of her brothers has a small heart-shaped one, an inch and a quarter in length, with a bow for suspension to the watch chain, ${ }_{3}^{1}$ which was given to him by an old Mrs. Nichols or Nicholson, who lived in Blytoncar, and was eighty-six when she died. At the time she gave it away, not long before her death, she said she knew it was made of car-oak, and was much older than she was, "because she had it from her grandmother when she was a girl." She added that farm-lads used to make such charms to give to their sweethearts on Valentine's Day. I have myself seen more modern ones cut out of cocoa-nut shell.

A. R. says that farm-men sometimes wear brass buttons with shanks, and little knife-shaped charms, on their watch-chains. These latter "look like mother-of-pearl, and are made from shells, or pieces of shells, which are sometimes ploughed up," (probably oyster-shells, carted on to the land with refuse). Old farm-labourers, and other elderly countrymen, who cling to ancient fashions, still like wearing seals, miniature corkscrews, horse's teeth (which they have found), or miniature horse-shoes, on their watch-chains. A coin with a hole in it, or a cowrie-shaped

1 Exhibited at Meeting, 20th Nov. 1907. See p. I. 
shell, may also be seen. The horse's tooth, the horse-shoe, and the coin, are no doubt generally lucky. As to the shell, A. R. says her grandfather told her it was to prevent its owner from being drowned. Personally I have always imagined that, originally at least, it was a love-charm. The Cypraide and shells of similar form are used in love-magic in some parts of Europe.

Mabel. Peacock.

Sundry Notes from West Somerset and Devon.

THE belief in "overlooking" and witchcraft generally does not pass away, though no special forms have come under my notice. Some five and twenty years ago a "hammer and nail" charm against overlooking was used by an old woman living near Combwich. The then vicar was scandalised to see the old lady hammering a large nail into the footprint of another woman who had just passed down the lane, and was informed that the maker of the footprint had overlooked the operator, and that this proceeding would counteract the spell.

An old woman living on Farringdon Hill up to a few years ago was always credited with uncanny powers, and it was said to be usual for horses to misbehave when passing near her cottage. She also overlooked the moving from one cottage to another of a neighbour, with the result that almost immediately after she had passed the door a dresser full of china, carefully set in place, overbalanced and fell. .

This firm belief in overlooking, I may add, is one with which the village doctor has to reckon, as the belief by a nervous patient that she is being so treated has an immensely retarding effect on a possible recovery.

In the matter of folk-medicine, Taunton Museum preserves two specimens of young ash-trees split for the purpose of passing children suffering from congenital hernia through, one having been used within the last twenty years.

A wych-elm by the road close to Cannington Park was made into a "shrew-tree" not more than six years ago, the scar 